\title{
Chromodomain-Helicase-DNA-Binding Protein 8
}

National Cancer Institute

\section{Source}

National Cancer Institute. Chromodomain-Helicase-DNA-Binding Protein 8. NCI

Thesaurus. Code C102442.

Chromodomain-helicase-DNA-binding protein 8 (2581 aa, $291 \mathrm{kDa}$ ) is encoded by the human CHD8 gene. This protein plays a role in chromatin remodeling that regulates transcription. 